\title{
Relationship between the Village Head and the Village Consultative Body in Handling Covid-19 in Ubung Village
}

\author{
Belinda Sam 1), Darwin Abd Radjak2), M Chairul Basrun Umanailo²) *, Andries

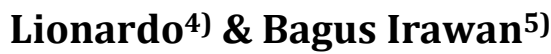

1) Law Science Faculty of Law, Universitas Iqra Buru, Indonesia

2) Universitas Muhammadiyah Maluku Utara, Indonesia

3) Agrotechnology, Faculty of Agriculture and Forestry, Universitas Iqra Buru, Indonesia

4) Universitas Sriwijaya, Palembang, Indonesia

5) Universitas Trunojoyo Madura, Indonesia

Received: 11 June 2021; Reviewed: 11 June 2021; Acepted: 11 August 2021

*Corresponding Email: chairulbasrun@gmail.com

\begin{abstract}
This study aims to establish a relationship between the village head and the village consultative body in Ubung, Buru Regency. The research problem is focused on the collaboration between the village head and the village consultative body in containing the spread of Covid-19 in Ubung. The study employed a qualitative approach, with a total of twenty informants chosen at random. This study was conducted in the village of Ubung, with informants including village officials, members of the Village Consultative Body, representatives of community leaders, traditional leaders, religious leaders, and community representatives considered to possess competencies relevant to the research objectives. This study collects data about the partnership relationship through observation and in-depth interviews. The analysis technique used is qualitative data analysis under Miles, Huberman, and Spradley's concepts. This study concludes that the village is extremely responsive in planning and implementing the management of Covid-19, making it easier for the community to be involved. The village side also adjusts to the existing conditions to carry out the control of Covid-19, specifically by conducting analysis and identification to decipher the program of activities that will plan in collaboration with the Village Consultative Body. In the Village Consultative Body tasks division, the village government prioritizes development sector implementation and public awareness, while the village government focuses more on-field segmentation planning.
\end{abstract}

Keywords: Partnership; Village Head; Village Consultative Body; Covid-19.

How to Cite: Sam, B., Radjak, D.A., Umanailo, M.C.B., Lionardo, A., \& Irawan, B., (2021). Relationship between the Village Head and the Village Consultative Body in Handling Covid-19 in Ubung Village. Jurnal Administrasi Publik (Public Administration Journal). 4 (1): 152-160 


\section{INTRODUCTION}

Since the beginning of 2020, the Covid-19 virus has progressed to a stage that is alarming almost every country, with a large number of deaths and transmissions resulting in a pandemic, forcing the government to issue regulations governing health protocols for individuals and institutions to stay alert and follow the health protocols that have been established. The condition of the spread of the Covid-19 virus that occurred in almost all of Indonesia has become a social problem that is still being addressed, as well as Ubung Village, which is located approximately 6 kilometers from the capital city of Buru district, has also felt the impact of the spread of the Covid-19 virus. Circulation and high population mobility require Ubung Village to manage their socio-economic life (Deri, 2017). In a pandemic situation, the role and apparatus of the village government become very important in carrying out appropriate steps to prevent the spread of the virus in the village.

The village government determines a very important relationship for local government implementation (Atmojo et al., 2017), especially the village head and the Village Consultative Body (BPD) as an integral part of the village administration. The village government is expected to be more responsive to the problems that occur in the village community. The village head and the Village Consultative Body have the authority to regulate the community through Village Regulations mutually agreed upon by the village community (Jamaluddin et al., 2018; Qhilby et al., 2017).

The village head is the highest village government apparatus, fully responsible for the welfare of the village community he manages, and his effectiveness has a significant impact on village progress. The supervisor to oversee the performance of the village head government is called the Village Consultative Body or what is often referred to as the BPD; with the establishment of the BPD, will achieve the balance of village government performance. Along with the supervisory function, the establishment of the BPD serves to accommodate and channel the aspirations of the village community, as well as the legislative function, namely collaborating with the village head in drafting Village Regulations, which will then be accounted for and reported to the community.

BPD is one component of village government. BPD members from various components of the village community become one of the most influential village leaders. BPD members are elected by villagers who have attained leadership positions in village organizations. It is not permissible for BPD members to also serve as village heads or village officials. (Awaeh, 2017; Simbolon \& Sembiring 2015; Ngarsiningtyas \& Sembiring 2016).

According to George Hillery Jr., a relationship is a group of people who live in a certain area and have a relationship of interaction with each other, which allows the group to get acquainted in the environment of the human group. Abdul Cheer argues that the relationship is meaningful, that there is interdependence between the organization and society that motivates organizations to form mutually beneficial relationships. Astuti asserts that relationships, or social relationships, result from frequent interactions (a series of behaviors) between two or more people. Can conclude that the relationship is a reciprocal relationship in which the organization interacts with other individuals or communities and influences each other. The public's attitude towards an organization in the future is very dependent on how information about the organization is obtained and how the public expresses their feelings about the organization (Santoso \& Erman, 2017).

Responding to the conceptual problem of the relationship between the 
village head and the BPD, this study defines it as a pattern of partnership relationships that can later assist in solving problems in Ubung village. This research is expected to describe the pattern of relationships and be a tool to establish relationships between the two agencies.

Previously, several studies focused on the partnership relationship between the village head and the village consultative body, including Khaeril Anwar's study on the working relationship between the Village Head and the Village Consultative Body according to Law Number 6 of 2014 concerning Villages (Anwar, 2015). Frisia Dwi Puspitarini, who analyzed the Partnership between the Village Consultative Body (BPD) and the Village Head in Drafting Village Regulations (a case study in Bakalanpule Village, Tikung District, Lamongan Regency) (Puspitarini et al., 2013). Ravi Santoso relations between village institutions in infrastructure development in Mayang Pongkai Village, Kampar Kiri Tengah District, Kampar Regency in 2016 (Santoso, 2017). The entire study is focused on the relationship between the two institutions, but no research has been done on the subject of dealing with Covid-19. This study aims to create a mapping document that will outline the partnership connection and serve as a guide for leaders in other villages.

\section{RESEARCH METHODS}

Researched Ubung village, Lilialy subdistrict, Buru district. Location determination is done intentionally. Ubung Village was chosen as the research location because it has community characteristics that represent the community in the Lilialy sub-district. Ubung Village is a village with a dominant identity from the Sula community and local communities in Buru Regency, most of which are livelihoods in agriculture, fisheries, trade, and services. The number of informants to be interviewed is 15 people who are considered parties involved in achieving the research objectives. Village officials, BPD members, representatives of community leaders, traditional leaders, religious leaders, and community representatives who are considered competent related to the purpose of the research become informants (Yusanto, 2020).

The data in this study were obtained from primary data sources and secondary data, with data collection techniques used through observation, interviews, and literature/document studies. Researchers conducted in-depth interviews with related parties in the field in response to the relationship between the village head and the BPD regarding the handling of Covid-19 in Ubung village. Researchers are looking for additional information about the development and handling of Covid-19 cases in Ubung Village through internet searches and literature reviews of government documents/archives related to village policies.

This study uses qualitative data analysis according to Miles, Huberman, and Spradley (Wijaya, 2018). The researcher engages in interactive analysis at each research stage to ensure that it is complete and that the data is saturated. Researchers carry out data analysis activities such as data reduction (data reduction), data presentation (data display), and drawing conclusions or verification (conclusion drawing/verification).

\section{RESULT AND DISCUSSION}

In response to the Covid-19 outbreak that has spread worldwide, including Indonesia, various policies have been set to provide a legal framework for handling Covid-19. Policies are applied differently in each country. Similarly, Indonesia has a single legal framework for implementing Covid-19 19, such as Government Regulation Number 21 of 2020 concerning Large-Scale Social Restrictions (PSBB) in 
the Context of Accelerating the Handling of Corona Virus Disease 2019 (Covid-19). Still, implementation requires a more flexible approach so that the community can follow it. Village administration is the smallest level of government in the local government administration system, with a special focus on village communities. The impact of this relationship, the performance of the village government, especially the village head and the Village Consultative Body (BPD) as the main instrument of government is very necessary, so the element of synergy between institutions is the main driver in village development (Rumkel et al., 2020; Wasistiono, 2019).

The village head and the Village Consultative Body (BPD) are two forms of village governance that are usually difficult to implement because these two village institutions are not in harmony from policy formulation to policy ratification. With the enactment of Law Number 6 of 2014 concerning Villages, it is hoped that these two institutions can work with the same vision and collaborate effectively in managing villages. The study conducted by Prihambodo conveyed the results of the development of village development. It was not in line with expectations and had not given significant results because of the lack of clear implementation (Prihambodo, 2019).

Partnership, in essence, is known as gotong-royong or cooperation from various parties, both individually and in groups. Cooperation essentially indicates the existence of two or more parties who interact and establish dynamic relationships to achieve common goals (Puspitarini et al., 2015).

In carrying out field research, researchers have interviewed approximately 15 informants divided into several characteristics, including; village officials, the BPD, community leaders and study mothers. In interviews, several informants (HI, KH and GF) said that the handling of Covid-19 around Ubung village was carried out by the village where there were rules made so that every community or newcomer could obey these regulations.

Some of the actions made by the community as a show of concern during the COVID-19 pandemic include protecting the entrance to Ubung village to prevent inhabitants from arriving from other locations designated as pandemic areas. This is done voluntarily. They not only guard the entrance post, but they also spray disinfectant at public facilities weekly.

During the researchers' discussion activities, the participants relayed several fascinating points, including the issue of the village party's, community leaders, and the Village Consultative Body's involvement. The researcher tries to elaborate these views through the following explanations; The whole community is given the task of protecting the environment and registering newcomers or residents who have just arrived in Ubung village to the RT/RW or the village; The community service program in the context of cleaning the village environment is carried out in turns arranged by the head of the local RT; The resident who was infected will be handled directly by the village in coordination with the Buru district health office; Banners, billboards and announcements regarding health protocols are the responsibility of the village; To maintain confusion about information regarding Covid-19 and patients, the village has opened information and complaint counter to serve villagers who need it.

An interview with GK stated that in planning and implementing the village's handling, the village was very responsible, making it easier for the community to actualize together in handling problems. In the implementation of Covid-19 control, the village adjusts to existing conditions, particularly by conducting analysis and identification to parse the program of activities that will plan at a later stage to be by the Ubung village development plan 
Belinda Sam, Darwin Abd Radjak, M Chairul Basrun Umanailo, Andries Lionardo \& Bagus Irawan, Relationship between the Village Head and the Village Consultative Body in Handling Covid-19 in Ubung Village

(Tenriawali et al., 2020). The village government formed a special team consisting of village officials and community members who have resources in the field of planning to conduct analysis and identification related to the short and medium-term management planning of the Covid-19 virus, which will then include in the development of the Ubung Village plan in the medium term. (RPJMDes).

According to the findings of interviews with JL informants, the analysis and identification process must be followed when planning a response to the spread of Covid-19 (Setyaningrum \& Wisnaeni, 2019). related to administrative analysis and identification process is very important as an administrative officer must identify and analyze administratively and then incorporate your findings into planning activities.

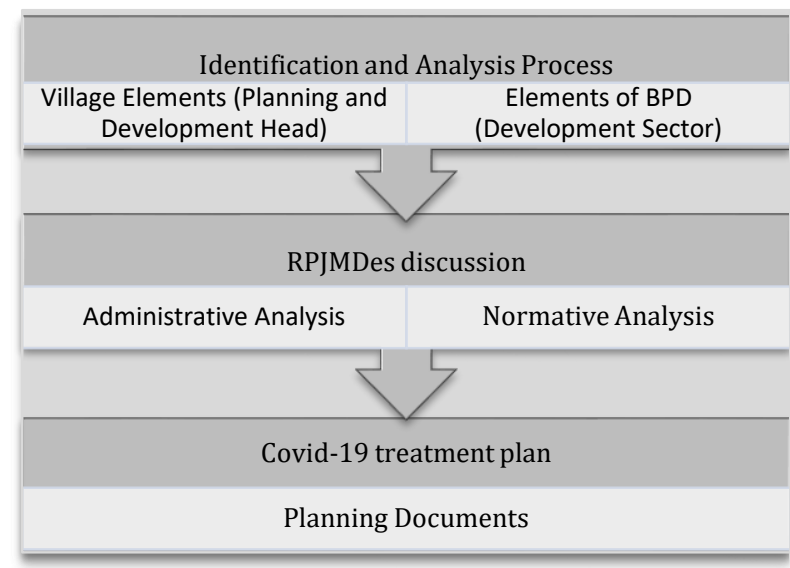

Figure1. The Planning Process for Handling the Spread of Covid-19 in Ubung Village

Based on the information gathered in the field through interviews with various stakeholders, the researcher conducted an analysis and identified the activities to be carried out in the context of handling, but also received input from several parties who argued that analysis and identification would be difficult due to budgetary constraints. Fully aware that handling activities are not only legal but also involve the use of human resources, which have the potential to change existing behaviors and habits so that they have an impact (Hilman
Pahlawan, 2019), the mapping of proposals between the village government and the BPD can be seen in Figure 2.

Based on Figure 2, the BPD prioritizes development implementation and community awareness, while the village government prioritizes fieldwork planning. The researcher's findings from interviews with several parties, including village heads, BPD heads, and community leaders, mapping the planning for handling the spread of Covid-19 refers to several conditions that exist in the village, namely the critical point is that planning and implementation have occurred through coordination and deliberation.

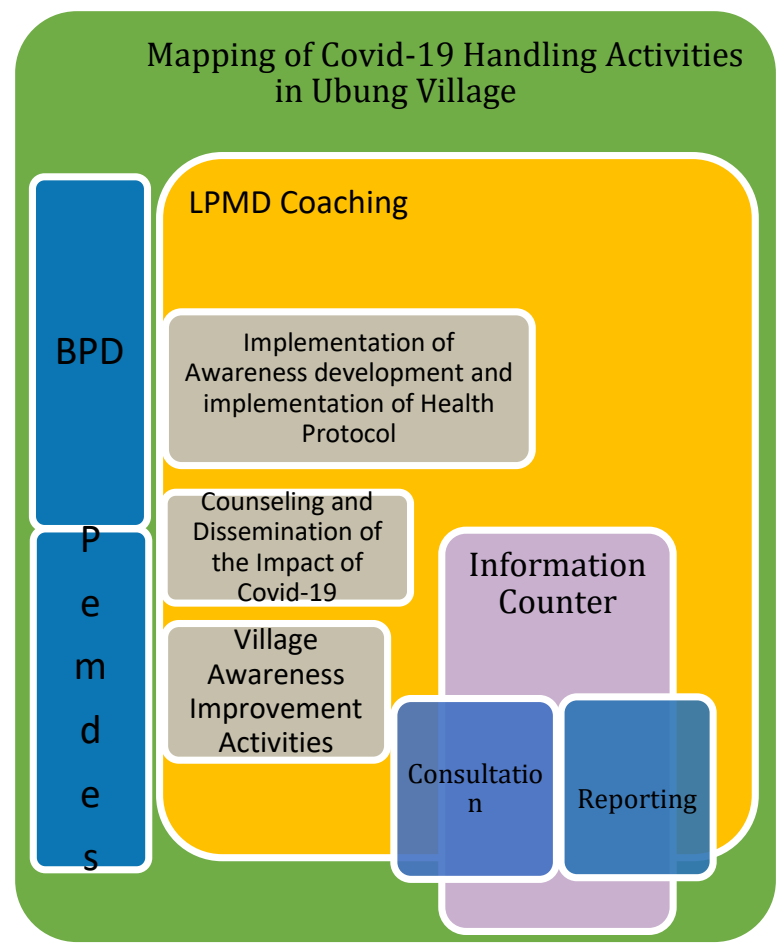

Figure 2. Mapping of Proposed Village Use

Institutional theory exemplifies the role of village institutions in village management. According to Huntington, social change can increase political awareness and participation on the one hand. Still, Huntington also ignores the source of authority afforded by traditional political institutions, creating a situation where new political institutions must step in to cover traditional political institutions (Rahma, Satya at, 2021). Huntington argues 
that the development of political institutions lags far behind the socioeconomic changes within Huntington. In Hanafie (2010), this theory is an organization, rules, and norms that are formal and informal for guidance in regulating behavior and community members, whether it is daily activities or to achieve the expected goals (Prihambodo, 2019).

A village is an area where the people live side by side, share the same customs and standards, and organize social life. According to Article 18B paragraph (2) of the 1945 Constitution, villages have been given customary authority. Should use the existence of the village and its original authority as one of the recognized human rights classifications in Indonesia. There is a need for organizations/institutions and figures/village heads who can mobilize the community to participate in village development in the administration of village governance. The Village Head is responsible to the people through the BPD. The joint responsibility of the Village Head in administering government can be seen as the embodiment of popular sovereignty (democracy) and its realization at the village level (Mawarni, 2018).

The cooperative relationship built is based on the division of labor between the village government and the BPD, as illustrated in table 1.

Table 1 shows that the village government makes a program proposal about the village government's work program. One of the informants $(\mathrm{KH})$ said, "The proposal to control the spread of Covid-19 by prioritizing awareness building for the village community and all village proposals is more effective". They were prioritizing handling proposals that were previously prepared through the village deliberation mechanism. As for the $\mathrm{BPD}$, the proposal is an aspiration that is accommodated through deliberation and consensus carried out by several members of the BPD. Because the BPD and the Village Head stipulate Village Regulations, the Village Head and the Village Consultative Body can be considered partners in administering Village Government. The Village Head directs the implementation of Village Government. At the same time, the BPD institutionally represents Village residents by acting as a supervisor for the implementation of Village Government. The role of the BPD is to accommodate and channel the aspirations of the village community. The Village Head and BPD are expected to have a common understanding and perspective in the administration of village government so that the implementation of village governance can be carried out under the expectations and demands of the community (Anwar, 2015).

According to Solekhan, the village government is responsible for government affairs, development, and society as an element of the village government. Thus, when viewed functionally, the village government carries out the following functions: 1) Organizing village government affairs; 2) Implementing community development and development; 3) Implement village economic development; 4) Implement development participation and cooperation; 5) Implement development. Development of community peace, and so on. The duties and functions of each institution, the relationship between the village head and the BPD are collaborative and based on the principle of checks and balances. As a result, village governance processes must create an environment conducive to a substantive democracy. Thus, the partnership relationship between the village head and the BPD must be based on mutual trust, cooperation, and mutual respect. If these three elements are present, the Partnership will run harmoniously. 
Belinda Sam, Darwin Abd Radjak, M Chairul Basrun Umanailo, Andries Lionardo \& Bagus Irawan, Relationship between the Village Head and the Village Consultative Body in Handling Covid-19 in Ubung Village

Table 1. The Role of Institutions in the Proposed Use of Village Funds

\begin{tabular}{|c|c|c|}
\hline \multirow[t]{2}{*}{ Institution } & \multicolumn{2}{|r|}{ Village Development } \\
\hline & Planning & Implementation \\
\hline \multirow[t]{5}{*}{ Village Government } & Data collection & Collecting data on new arrivals from out of town \\
\hline & $\begin{array}{l}\text { Public } \\
\text { Improvement }\end{array}$ & $\begin{array}{l}\text { Providing Soap and Water at } 20 \text { points around } \\
\text { Ubung Village }\end{array}$ \\
\hline & Awareness Raising & $\begin{array}{l}\text { Making billboards, banners and providing free } \\
\text { masks at the village office }\end{array}$ \\
\hline & $\begin{array}{l}\text { Environmental quality } \\
\text { improvement }\end{array}$ & $\begin{array}{l}\text { Implementation of the "Clean Friday" initiative } \\
\text { and Sunday social services }\end{array}$ \\
\hline & $\begin{array}{l}\text { Improved information } \\
\text { services }\end{array}$ & $\begin{array}{l}\text { Procurement of Consultation and Reporting } \\
\text { Counters }\end{array}$ \\
\hline \multirow[t]{3}{*}{ BPD } & $\begin{array}{l}\text { Strengthening village } \\
\text { budgets in the context of } \\
\text { handling Covid-19 }\end{array}$ & Inventory of village financial resources \\
\hline & $\begin{array}{l}\text { Consciousness } \\
\text { Strengthening }\end{array}$ & $\begin{array}{l}\text { Limited meeting of residents to increase } \\
\text { understanding of the spread of Covid-19 }\end{array}$ \\
\hline & $\begin{array}{lr}\text { Contribute to the } \\
\text { improvement } \\
\text { environmental quality }\end{array}$ & $\begin{array}{l}\text { Regular participation of the community in } \\
\text { community service activities }\end{array}$ \\
\hline
\end{tabular}

Source: Data Primer Processing, Maret-Juni 2021

\section{CONCLUSION}

The performance of the village government apparatus, which includes the village government and the Village Consultative Body, is part of the community's desire so that the village government and BPD can work properly and correctly in the village development process. The village head must be capable of managing village administration, managing resources, and providing services to the community, all of which are backed by BPD policies and oversight. Due to the harmonious relationship between the two institutions, the conditions for handling Covid-19 in Ubung village can be well interpreted in line with this desire. The synergy between village institutions is essential to successfully implement village development activities and efforts to solve village problems.

\section{ACKNOWLEDGMENTS}

The author's gratitude goes to the Directorate of Research and Community Service of the Ministry of Research, Technology and Higher Education, who has provided the opportunity to research through the 2020 Beginner Lecturer
Research scheme grant. In addition, the authors also thank the Head of the Institute for Research and Community Service (LPPM), Head of the Center for Planning Studies Community Development (PSP2M) Iqra Buru University for the support given during the research and writing of this article to completion.

\section{REFERENCES}

Anwar, K. (2015). Hubungan Kerja Antara Kepala Desa Dengan Badan Permusyawaratan Desa ( Bpd ) Menurut Undang-Undang Nomor 6 Tahun 2014 Tentang Desa Working Relation Between Head of the Village and Consultative Body of the Village ( Bpd ) According To Law. IUS Kajian Hukum Dan Keadilan, III(8), 207222.

https://doi.org/http://dx.doi.org/10.12345 /ius.v3i8.208

Atmojo, M. E., Fridayani, H. D., Kasiwi, A. N., \& Pratama, M. A. (2017). Efektivitas dana desa untuk pengembangan potensi ekonomi berbasis partisipasi masyarakat di Desa Bangunjiwo. Aristo, 5(1), 126-140. https://doi.org/10.31227/osf.io/cmk7h

Awaeh, S. (2017). Peranan Badan Permusyawaratan Desa (BPD) Dalam Penyelenggaraan Pengawasan Pemerintahan (Studi di Desa Sereh 1 Kecamatan Lirung Kabupaten Talaud). JURNAL EKSEKUTIF, 1(8), 1-11.

Deri. (2017). Peran Badan Permusyawaratan Desa (BPD) dalam pengawasan pengelolaan 
APBDes di Desa Senambah Kecamatan Muara Bengkal Kabupaten Kutai Timur. E-Journal Ilmu Pemerintahan, 5(1), 121-132.

Mawarni, N. A. (2018). Hubungan Kepala Desa Dan Badan Permusyawaratan Desa (Bpd) Dalam Penyusunan Anggaran Pendapatan Dan Belanja Desa ... [Universitas Islam Indonesia]. https://dspace.uii.ac.id/handle/123456789/ 5652

PRIHAMBODO, O. G. P. (2019). Relasi Kepala Desa Dan Bpd Dalam Implementasi Dana Desa Di Desa Siwalanpanji, Kecamatan Buduran, Kabupaten Sidoarjo. Jurnal Politik Muda, 7(3), 108-118.

http://repository.unair.ac.id/id/eprint/880 52

Puspitarini, F. D., Supriyono, B., \& Suwondo. (2013). Kemitraan Badan Permusyawaratan Desa (Bpd) Dengan Kepala Desa Dalam Penyusunan Peraturan Desa. Jurnal Administrasi Publik, 1(4), 41-47. http://administrasipublik.studentjournal.ub. ac.id/index.php/jap/article/view/133/117

Puspitarini, F. D., Supriyono, B., \& Suwondo. (2015). Kemitraan Badan Permusyawaratan Desa (BPD) Dengan Kepala Desa Dalam Penyusunan Peraturan Desa. Jurnal Administrasi Publik, 1(4), 41-47. https://media.neliti.com/media/publication s/74397-ID-kemitraan-badanpermusyawaratan-desa-bpd.pdf

Rahma, Satya at, A. (2021). Modernisasi Terhadap Perubahan Sosial Masyarakat Desa Namlea Kabupaten Buru. Nusantara: Jurnal Ilmu Pengetahuan Sosial, 8(1), 84-96. https://doi.org/doi.org/10.31604/jips.v8i1. 2021.84-96

Rumkel, L., Sam, B., \& Umanailo, M. C. B. (2020). Hubungan Kepala Desa, Badan Permusyawaratan Desa Serta Lembaga Adat Dalam Pelaksanaan Pembangunan Desa. Subplane Covered Nets, 11(1), 85-98. https://doi.org/10.1201/9781482293449-8

Santoso, R. (2017). Relasi Antar Kelembagaan Desa Dalam Pembangunan Insfratruktur Di Desa Mayang Pongkai Kecamatan Kampar Kiri Tengah Kabupaten Kampar Tahun 2016. JOM FISIP, 4(2).

Santoso, R., \& Erman. (2017). Relasi Antar Kelembagaan Desa Dalam Pembangunan
Infrastruktur di Desa Mauang Pongkai Kecamatan Kampar Kiri Tengah Kabupaten Kampar Tahun 2016. Jurnal Online Mahasiswa Fakultas Ilmu Sosial Dan Ilmu Politik Universitas Riau, 4(2), 1-12.

Setyaningrum, C. A., \& Wisnaeni, F. (2019). Pelaksanaan Fungsi Badan Permusyawaratan Desa Terhadap Penyelenggaraan Pemerintahan Desa. Jurnal Pembangunan Hukum Indonesia, 1(2), 158-170. https://doi.org/10.14710/jphi.v1i2.158-170

Tenriawali, A. Y., Suryani, S., Hajar, I., \& Umanailo, M. C. B. (2020). Efek Hoax Covid-19 Bagi Igeneration Di Kabupaten Buru. Potret Pemikiran, 24(2), 123-142. http://journal.iain-

manado.ac.id/index.php/PP/article/view/1 $201 / 0$

Wijaya, H. (2018). Analisis Data Kualitatif Model Spradley (Etnografi). Sekolah Tinggi Theologia Jaffray, 3(1), 1-10.

Yusanto, Y. (2020). Ragam Pendekatan Penelitian Kualitatif. JOURNAL OF SCIENTIFIC COMMUNICATION (JSC), 1(1). https://doi.org/10.31506/jsc.v1i1.7764

Jamaluddin, Y. Sumaryana, A. Rusli, B. \& Buchari, R.A. (2018). Analisis Dampak Pengelolaan dan Penggunaan Dana Desa terhadap Pembangunan Daerah. JPPUMA: JPPUMA: Jurnal Ilmu Pemerintahan dan Sosial Politik UMA (Journal of Governance and Political UMA), 6 (1): 14-24.

Qhilby, Tarigan, U, Dewi, R (2017). Peranan Badan Permusyawaratan Desa dalam Perencanaan Pembangunan Desa. PERSPEKTIF, 6 (2): 4152.

Simbolon, A.H., dan Sembirng, W.M., (2015). Evaluasi Kinerja Badan Permusyawaratan Desa dalam Penyelenggaraan Pemerintahan Desa, JPPUMA: Jurnal Ilmu Pemerintahan dan Sosial Politik UMA (Journal of Governance and Political UMA), 1 (1): 143-159.

Ngarsiningtyas, S.K., dan Sembiring, W.M., (2016) Peran Badan Permusyawaratan Desa dalam Penyusunan dan Penetapan Peraturan Desa, JPPUMA: Jurnal Ilmu Pemerintahan dan Sosial Politik UMA (Journal of Governance and Political UMA), 4 (2): 159-172. 